\title{
PEMISAHAN ANION MENGGUNAKAN FASA DIAM HILIC IMIDAZOL PADA HYDROPHILIC INTERACTION LIQUID CHROMATOGRAPHY DENGAN PENAMBAHAN GARAM AMMONIUM ASETAT
}

\author{
Dyna Putri Mayaserli \\ STIKes Perintis Padang. Jalan Adinegoro KM 17 Simpang Kalumpang Padang \\ Email: dyna2205@yahoo.com
}

\begin{abstract}
The need to detect anions and cations in a variety of environmental water samples more rapidly along with the increasing environmental problems and the time required analytical methods are precise, fast, simple and can provide an accurate assessment. Hydrophilic Interaction Liquid Chromatography (HILIC) is an extremely precise technique for separating polar compounds or compounds that are hydrophilic. The purpose of this study is to assess the separation of anions using HILIC stationary phases imidazole in hydrophilic interaction liquid chromatography with the addition of ammonium acetate salt. From the research that has been done can be concluded Imidazoles HILIC can separate SCN- anion, NO 3, NO 2, Br, and I- BrO3using acetonitrile mobile phase. The addition of salt Ammonium Acetate in the mobile phase can increase the sensitivity and selectivity of anions. So that the resulting peak sharper and bigger.
\end{abstract}

Key words: HILIC Imidazol, anion, HILIC

\section{PENDAHULUAN}

Kromatografi merupakan suatu teknik pemisahan molekul berdasarkan perbedaan pola pergerakan antara fase gerak dan fase diam untuk memisahkan komponen yang berada pada larutan. Molekul yang terlarut dalam fase gerak, akan melewati kolom yang merupakan fasa diam (McKay, 2010). Molekul yang memiliki ikatan yang kuat dengan kolom akan cendrung bergerak lebih lambat dibanding molekul yang berikatan lemah. Sehingga berbagai macam tipe molekul dapat dipisahkan berdasarkan pergerakan kolom.

$$
\text { High Performance Liquid }
$$

Chromatography (HPLC) merupakan jenis kromatografi dimana komponen yang dipisahkan dilewatkan melalui fasa diam dalam kolom dan fasa gerak cairan yang dialirkan dengan tekanan yg diikuti dengan pemisahan campuran dengan resolusi tinggi. HPLC merupakan teknik analisis yang sangat cepat berkembang dalam bidang analitik dan penggunaannya juga sudah banyak digunakan dalam berbagai bidang. HPLC mempunyai prinsip yang mirip dengan kromatografi fasa normal (normal phase chromatography). Hanya saja dalam metode ini digunakan tekanan dan kecepatan yang tinggi. Kolom yang digunakan dalam HPLC lebih pendek dan berdiameter kecil, namun dapat menghasilkan beberapa tingkatan equilibirium dalam jumlah besar (Carrier, 1997).

Kebutuhan untuk pendeteksian anion dan kation dalam berbagai sampel air lingkungan semakin pesat seiring dengan meningkatnya masalah lingkungan (environmental problems) dan saatnya dibutuhkan metoda analisis yang tepat, cepat, sederhana dan dapat memberikan analisis yang akurat. Hydrophilic Interaction Liquid Chromatography (HILIC) merupakan teknik yang sangat tepat untuk memisahkan senyawa polar atau senyawa yang bersifat hidrofilik dan juga senyawa biological aktif seperti obat obatan, nukleosida, nukleotida, asam amino, peptida, protein, oligosakarida, karbohidrat dan lain - lain (Alpert,1990) 
Saat ini berbagai tempat pembuatan kolom kromatografi telah banyak memasarkan berbagai jenis fasa diam yng dibuat khusus untuk proses HILIC seperti HILIC Silika dan ZIC HILIC (Eric, 2004). Dengan adanya berbagai jenis fasa diam yang berbeda dan banyak pilihan sesuai dengan senyawa atau komponen yang akan dipisahkan, maka kita harus dapat memilih kolom yang benar dan tepat yang sesuai dengan komponen yang akan kita pisahkan. Beberapa penelitian sebelumya menggunakan metoda HILIC yang memakai fasa diam polar, pada umumnya menggunakan sampel organik dan hanya sedikit yang menggunakan sampel ion (anorganik) (Guo Yong, 2005). Pemisahan anion menggunakan fasa diam octadecylsilika yang dimodifikasikan dengan bovine serum albumin (R.Zein, 1996), anion dapat terpisah sempurna.

Oleh karena itu dibutuhkan penelitian lebih lanjut mengenai jenis fasa diam polar lainnya untuk pemisahan terutama sampel ion (anorganik) dan juga untuk menambah pengetahuan tentang pemisahan sampel anion menggunakan metoda HILIC. Penelitian ini bertujuan untuk melihat karakteristik HILIC Imidazol, sebagai fasa diam polar yang digunakan untuk pemisahan anion pada proses HILIC (Hydrophilic Interaction Chromatography).

\section{METODE PENELITIAN}

Alat dan bahan yang dibutuhkan adalalah data Processor CDS (Shimadzu, Kyoto, Japan), UV Detector (Jasco, Tokyo, Japan), Injector Volume 0,2 0,2 $\mu \mathrm{L}$ (Rheodyne, Cotati, CA, USA), mikrofeder (L.TEX
Corporation, Tokyo, Japan), kolom silica (100 mm x 0,32 mm ID x 0,75 mm OD), PTFE (0,25 $\mathrm{mm} \times 1 / 16 \mathrm{~mm}),(0,26 \mathrm{~mm} \times 2 \mathrm{~mm}),(2 \mathrm{~mm} \times$ $1 \mathrm{~mm}),(4 \mathrm{~mm} \times 2 \mathrm{~mm})$, stainlesstel, kapas, syringe 0,5 mL ; 0,1 mL ; 0,25 mL (Ito, Fuji, Japan), timbangan dan peralatan gelas lainnya.

Hilic Imidazol (Sepax Technologies, Japan), Asetonitril (Kanto Chemical, Japan), Metanol (Wako Pure Chemical Industries), IC Water, Ammonium asetat (Nacalai Tesque, Japan), Asam asetat (Nacalai Tesque, Japan), Natrium asetat (Nacarai Chemicals, Japan), Asam klorida (Nacalai Tesque, Japan), Natrium klorida (Nacalai Tesque, Japan), Tri Fluoro Acid (Nacalai Tesque, Japan), Natrium bikarbonat (Nacalai Tesque, Japan), Natrium Bromat (Nakalai Tesque, Japan), Natrium Bromida (Nakarai Tesque, Japan), Natrium Iodida (Nakarai Tesque, Japan), Natrium Nitrat (Nakarai Tesque, Japan), Natrium Nitrit (Nakarai Tesque, Japan), Natrium Tiosianat (Nakalai Tesque, Japan)

\section{Pembuatan Kolom}

Kolom capillary sepanjang $10 \mathrm{~cm}$ yang telah diisi dengan fasa diam polar dengan menggunakan konektor, tanpa rongga udara di tutup kedua ujungnya menggunakan Teflon Tube (PTFE) sebanyak 3 lapis dengan ukuran masing-masingnya $0,25 \mathrm{~mm} \times 1 / 16 \mathrm{~mm}, 2 \mathrm{~mm}$ x $1 \mathrm{~mm}$ dan $4 \mathrm{~mm}$ x $2 \mathrm{~mm}$, agar kolom tidak leeking. Pada salah satu bagian di beri Quartz Glass Wool agar fasa diam yang telah diisi tidak keluar. Setelah itu pada ujung Teflon tube diberi Stainless Steel Tube sebagai penyambung untuk disambungkan dengan sistim peralatan HPLC.

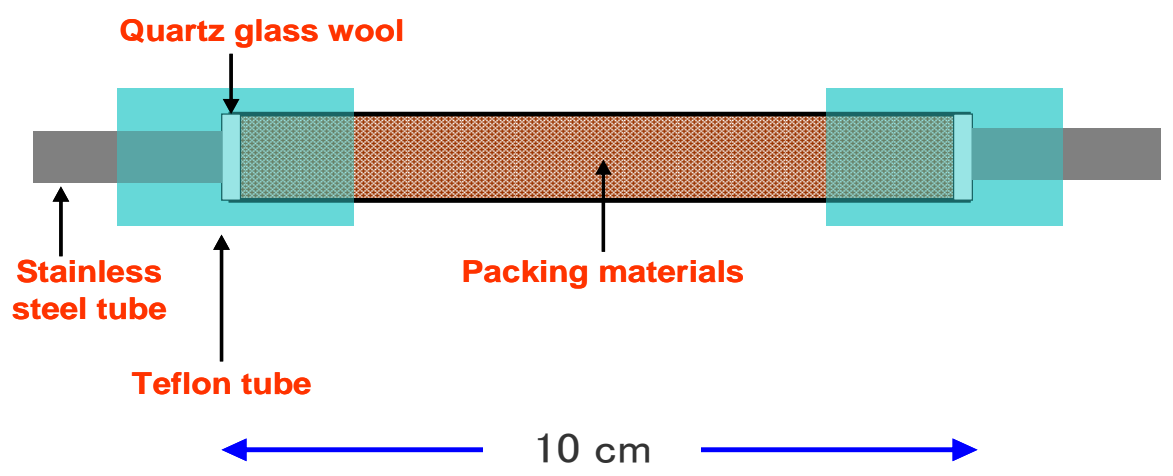

Gambar 1. Bagian-bagian kolom capillary 


\section{Persiapan Kolom}

Fasa diam polar masing-masingnya $\left(\mathrm{NH}_{2}-60\right.$, HILIC Imidazol, Polar Piridin, Amid-80) disiapkan secukupnya di dalam botol kecil. Kemudian dilarutkan dengan menggunakan metanol $100 \%$, aduk hingga rata sampai membentuk bubur (tidak terlalu encer dan tidak terlalu pekat). Setelah itu fasa diam dimasukkn ke dalam kolom silica yang telah dibuat dengan panjang $10 \mathrm{~cm}$ dan diameternya $0,32 \mathrm{~mm}$ menggunakan konektor seperti terlihat pada gambar 8. Setelah kolom silica selesai di packing, kolom di pasang pada sistim $H P L C$ yang akan digunakan.

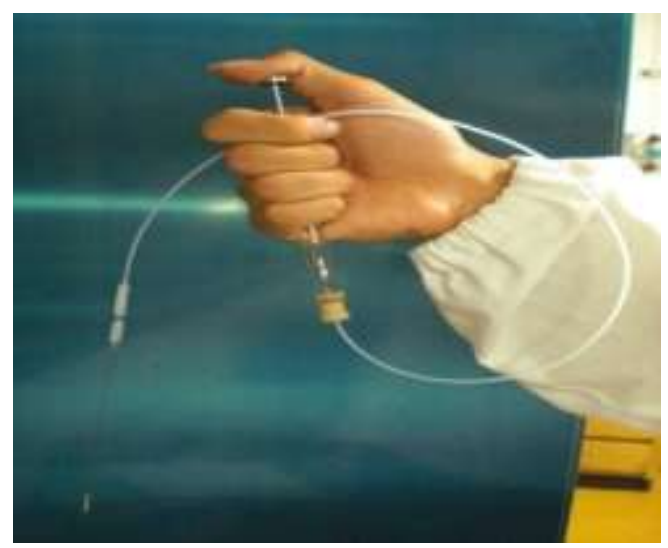

Gambar 2. Cara menginjeksi fasa diam ke dalam kolom

\section{Pembuatan Eluen}

Asetonitril $100 \%$ sebagai eluent dilarutkan di dalam air IC (Ion Chromatography) yaitu air yang khusus digunakan untuk melarutkan dalam kromatografi dengan perbandingan 7:3, 8:2, 9:1. Apabila menggunakan garam ammonium asetat dibuat variasi konsentrasi ammonium asetat 10, 20, 30, 40, $50 \mathrm{mM}$. kemudian dibuat perbandingan antara asetonitril dan ammonium asetat 7:3, 8:2, 9:1. Eluen dimasukkan ke dalam syringe $0,5 \mathrm{~mL}$ tanpa gelembung udara. Syringe kemudian di pasang pada sistim HPLC.

\section{Pemisahan anion berdasarkan variasi laju alir}

Kolom yang telah diisi dengan fasa diam HILIC Imidzol di pasang pada sistim peralatan HPLC. Siapkan eluen asetonitril : ammonium asetat (8:2) dan dimasukkan ke dalam syiringe $0,5 \mathrm{~mL}$, setelah itu syiringe di pasang pada microfeeder. Variasi laju alir yang digunakan yaitu : $2,0 \mu \mathrm{L} / \mathrm{min}, 2,5 \mu \mathrm{L} / \mathrm{min}$ dan $3,0 \mu \mathrm{L} / \mathrm{min}$ . Detektor diatur pada panjang gelombang 210 $\mathrm{nm}$. 6 analit dipisahkan menggunkan sistim peralatan HPLC.

\section{Pemisahan anion menggunakan asetonitril dengan variasi konsentrasi ammonium asetat}

Kolom yang telah diisi dengan fasa diam HILIC Imidazol di pasang pada sistim peralatan HPLC. Siapkan eluen asetonitril : ammonium asetat (8:2) dan garam Ammonium Asetat dengan variasi konsentrasi 10, 20, 30, 40 dan $50 \mathrm{mM}$, dimasukkan ke dalam syiringe $0,5 \mathrm{~mL}$, setelah itu syiringe di pasang pada microfeeder. Kecepatan alir yang digunakan yaitu : $3,0 \mu \mathrm{L} / \mathrm{min}$. Detektor diatur pada panjang gelombang $210 \mathrm{~nm}$. 6 analit dipisahkan menggunkan sistim peralatan HPLC.

\section{Pemisahan anion berdasarkan variasi konsentrasi asetonitril}

Kolom yang telah diisi dengan fasa diam HILIC Imidazol di pasang pada sistim peralatan HPLC. Siapkan eluen asetonitril : 50 $\mathrm{mM}$ ammonium asetat. Konsentrasi asetonitril divariasikan yaitu $60 \%, 70 \%$ dan $80 \%$.Setelah itu dimasukkan ke dalam syiringe $0,5 \mathrm{~mL}$, dan syiringe di pasang pada microfeeder. Kecepatan laju alir yang digunakan yaitu : 3,0 
$\mu \mathrm{L} / \mathrm{min}$. Detektor diatur pada panjang gelombang $210 \mathrm{~nm}$. 6 analit dipisahkan menggunkan sistim peralatan $H P L C$.
HASIL DAN PEMBAHASAN

Pemisahan Anion Berdasarkan Variasi Laju Alir

Pemisahan anion menggunakan HILIC Imidazol dengan variasi laju alir dapat dilihat pada kromatogram. Variasi laju alir yang digunakan adalah $2,0 \mu \mathrm{L} / \mathrm{min}, 2,5 \mu \mathrm{L} / \mathrm{min}$ dan $3,0 \mu \mathrm{L} / \mathrm{min}$.

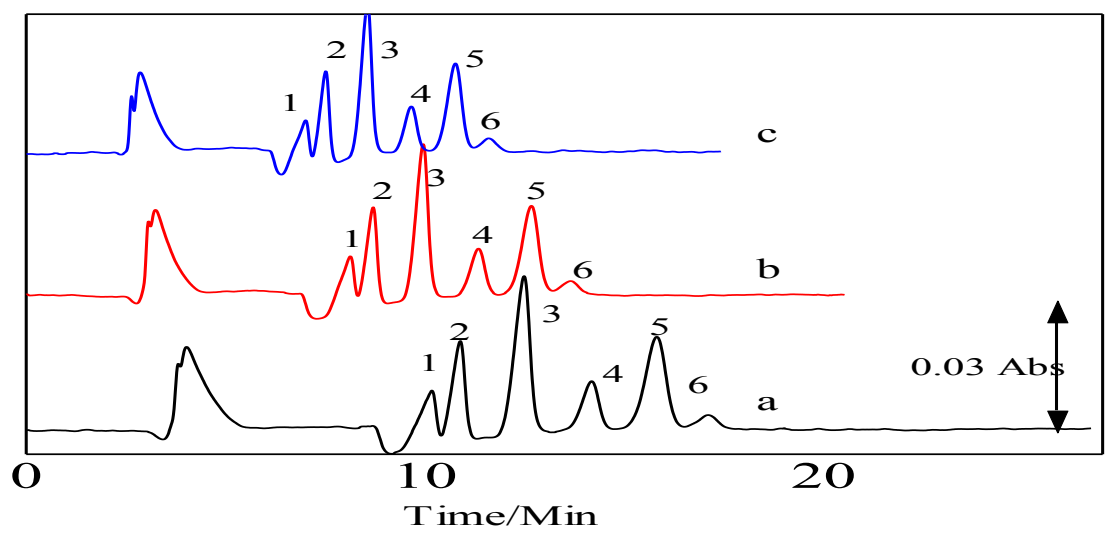

Gambar 3 Pemisahan anion menggunakan HILIC Imidazol (100 x 0,32 mm ID). Fasa Gerak:

Asetonitril dalam ammonium asetat (8:2). Laju Alir (a) 2,0 mL/min (b) 2,5 mL/min (c) 3,0 $\mathrm{mL} / \mathrm{min}$. UV Detektor pada $210 \mathrm{~nm}$. Anion: (1) $\mathrm{SCN}^{-}$(2) $\mathrm{I}^{-}$(3) $\mathrm{NO}_{3}^{-}$(4) $\mathrm{Br}^{-}$(5) $\mathrm{NO}_{2}^{-}$(6) $\mathrm{BrO}_{3}^{-}$ $1 \mathrm{mM}$

Dari kromatogram dapat dilihat kecepatan laju alir yang paling baik adalah pada laju alir 3,0 $\mu \mathrm{L} / \mathrm{min}$. Pada laju alir 2,0 $\mu \mathrm{L} / \mathrm{min}$ dan $2,5 \mu \mathrm{L} / \mathrm{min}$ waktu yang dibutuhkan untuk memisahkan 6 anion lebih lama berkisar antara $13-18$ menit. Sedangkan pada laju alir 3,0 $\mu \mathrm{L} / \mathrm{min}$ waktu yang dibutuhkan hanya 11 menit. Pada fasa gerak asetonitril ditambah dengan garam ammonium asetat karena tanpa penambahan garam ammonium asetat, fasa diam HILIC Imidazol tidak dapat memisahkan anion. Sehingga puncak yang dihasilkan cuma satu dan semua anion tergabung di dalamnya. Anion yang tergabung tersebut dapat dipisahkan dengan menambahkan garam ammonium asetat ke dalam fasa gerak asetonitril. Manfaat memvariasikan laju alir adalah untuk melihat waktu yang paling optimum dalam proses pemisahan anion. Sehingga dari laju alir optimum tersebut dapat digunakan untuk pemisahan anion dengan variasi yang lainnya.

\section{Pemisahan Anion Menggunakan Asetonitril Dengan Penambahan Ammonium Asetat}

Konsentrasi Ammonium asetat yang digunakan divariasikan untuk melihat konsentrasi yang bagus untuk pemisahan anion. Variasi yang digunakan adalah 10, 20, 30, 40, dan $50 \mathrm{mM}$. Pemisahan anion menggunakan HILIC Imidazol terlihat pada kromatogram. Anion dapat terpisah sempurna walaupun $\mathrm{BrO}_{3}^{-}$hanya membentuk puncak yang kecil dan agak broad. Waktu yang dibutuhkan untuk memisahkan ke 6 anion lebih sedikit dibanding menggunakan fasa diam Aminopropil Silika. Waktu yang dibutuhkan memisahkan anion menggunakan HILIC 
Imidazol adalah kurang dari 12 menit. waktu yang dibutuhkan untuk memisahkan 6 Sedangkan menggunakan Aminopropil Silika anion adalah 20 menit.

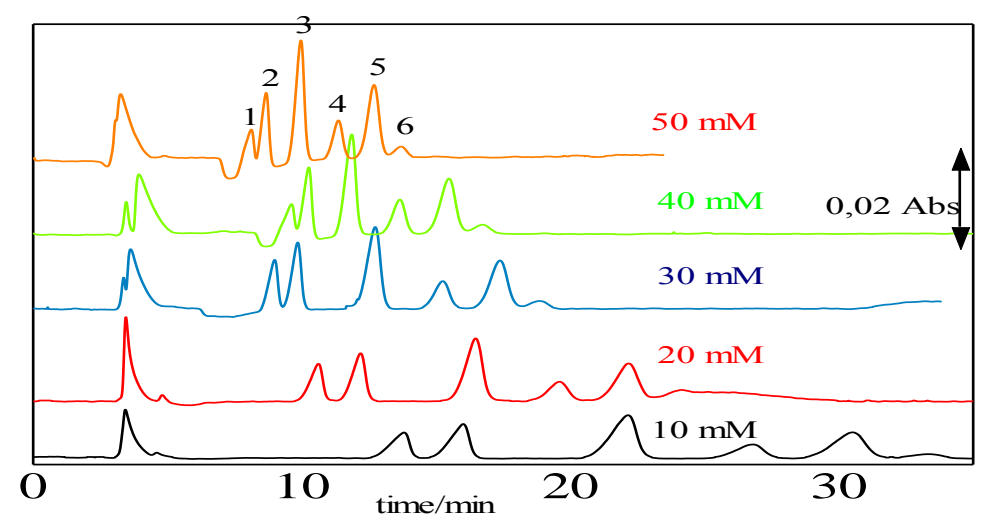

Gambar 4 Pemisahan anion menggunakan HILIC Imidazol (100 x 0,32 mm ID). Fasa Gerak: Asetonitril (80\%) dalam ammonium asetat (a) $10 \mathrm{mM}$, (b) $20 \mathrm{mM}$, (c) $30 \mathrm{mM}$, (d) $40 \mathrm{mM}$, (e) $50 \mathrm{mM}$. Laju Alir 3,0 mL/min. UV Detektor pada $210 \mathrm{~nm}$. Anion: (1) $\mathrm{SCN}^{-}$(2) $\mathrm{I}^{-}$(3) $\mathrm{NO}_{3}^{-}$(4)

$$
\mathrm{Br}^{-}(5) \mathrm{NO}_{2}^{-} \text {(6) } \mathrm{BrO}_{3}^{-} 1 \mathrm{mM}
$$

Walaupun waktu pemisahannya lebih cepat tetapi fasa gerak yang digunakan untuk pemisahan anion harus ditambah dengan garam ammonium asetat. Apabila tidak menambahkan kan garam ammonium asetat, hanya membentuk satu puncak dengan kata lain anion tidak terpisahkan. Ammonium Asetat dapat meningkatkan selektivitas dan sensitivitas dari pemisahan. Jadi konsentrasi ammonium asetat yang paling baik adalah 50 $\mathrm{mM}$. Anion dapat terpisah dengan sempurna dan pnvak yang dihasilkan lebih tajam (shape).

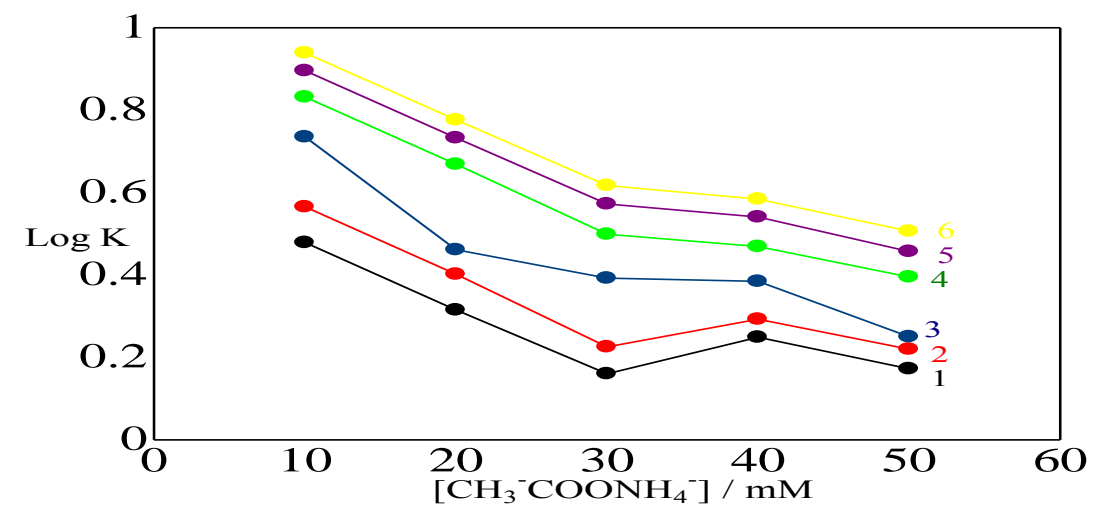

Gambar 5 Logaritma faktor retensi sebagai fungsi dari konsentrasi garam ammonium asetat pada fasa gerak untuk Gambar 4 
Pemisahan Anion Berdasarkan Variasi Konsentrasi Asetonitril

Pemisahan anion menggunakan HILIC Imidazol dapat dilihat pada kromatogram. Variasi fasa gerak yang digunakan yaitu asetonitril : ammonium asetat $(6: 4,7: 3$ dan $8: 2$ ). Kondisi optimum yang paling bagus untuk pemisahan 6 analit menggunakan HILIC Imidazol adalah asetonitril : ammonium asetat (8:2), konsentrasi optimum ammonium asetat adalah $50 \mathrm{mM}$, dengan laju alir $2,5 \mu \mathrm{L} /$ menit dan konsentrasi masing-masing analit adalah 1 $\mathrm{mM}$.

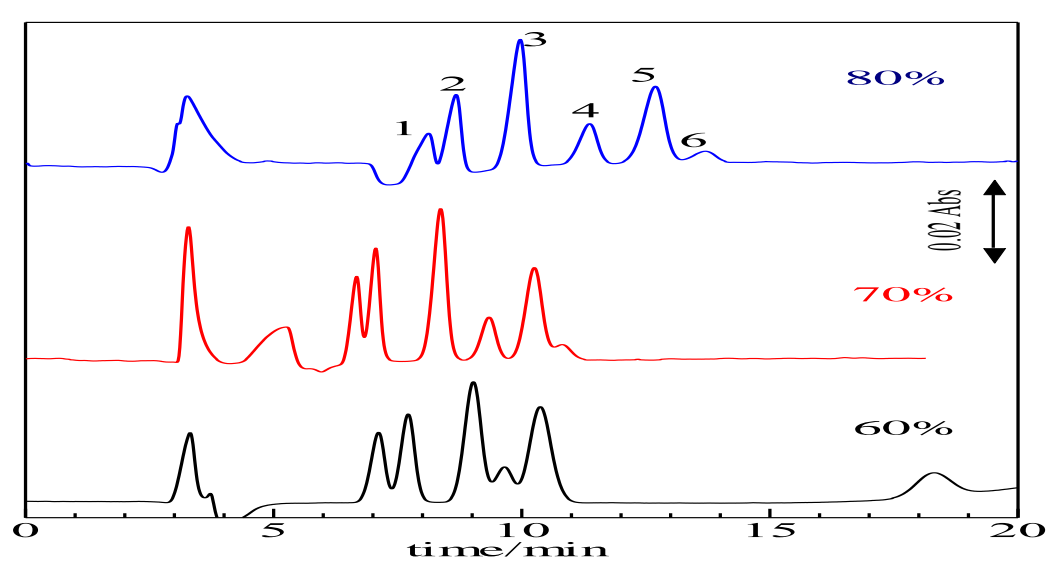

Gambar 6 Pemisahan anion menggunakan HILIC Imidazol (100 x 0,32 mm ID). Fasa Gerak: Asetonitril dalam $50 \mathrm{mM}$ Ammonium Asetat (a) $60 \%$ (b) $70 \%$ (c) $80 \%$. Laju Alir 3,0 mL/min. UV Detektor pada $210 \mathrm{~nm}$. Anion: (1) $\mathrm{SCN}^{-}$(2) $\mathrm{I}^{-}$(3) $\mathrm{NO}_{3}^{-}$(4) $\mathrm{Br}^{-}$(5) $\mathrm{NO}_{2}^{-}$(6) $\mathrm{BrO}_{3}^{-} 1 \mathrm{mM}$

Pada kromatogram dapat dilihat bahwa pemisahan yang paling baik adalah pada konsentrasi asetonitril $80 \%$. Walaupun waktu yang dibutuhkan untuk memisahkan anion lebih lama dari konsentrasi asetonitril $70 \%$ yaitu dengan Rt 13,5 menit. Sedangkan pada konsentrasi $60 \%$ dan $70 \%$ waktunya lebih cepat yaitu sekitar 11 menit, tetapi pemisahan tidak sempurna karena masih ada anion yang belum terpisahkan dengan sempurna.

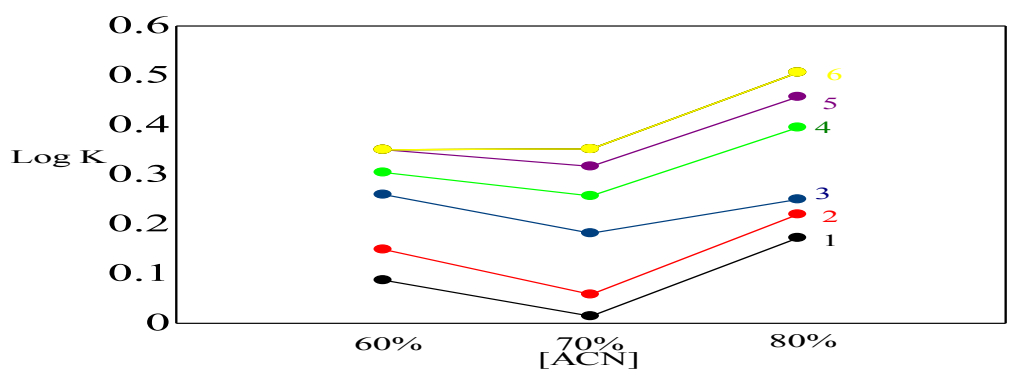

Gambar 7 Logaritma faktor retensi sebagai fungsi dari konsentrasi asetonitril pada fasa gerak untuk Gambar 6

Anion dapat dipisahkan menggunakan HILIC Imidazol karena adanya interaksi hidrofilik yang terjadi antara fasa diam, fasa gerak dan analit. Prinsip HILIC Imidazol sama 
dengan Aminopropil Silika, tetapi urutan anion yang terpisahkan berbeda antara HILIC Imidazol dan Aminopropil Silika.

\section{KESIMPULAN}

Dari penelitian yang telah dilakukan dapat diambil kesimpulan HILIC Imidazol dapat memisahkan anion $\mathrm{SCN}^{-}, \mathrm{NO}_{3}^{-}, \mathrm{NO}_{2}^{-}, \mathrm{Br}$ , $\mathrm{BrO}_{3}{ }^{-}$dan $\mathrm{I}^{-}$dengan menggunakan fasa gerak Asetonitril. Penambahan garam Ammonium Asetat pada fasa gerak dapat meningkatkan kesensitifan dan keselektivan dari anion. Sehingga puncak yang dihasilkan lebih tajam dan lebih besar.

\section{DAFTAR KEPUSTAKAAN}

Albert, A.J. Hydrophilic-Interaction Chromatography for the Separation of Peptides, Nucleic Acids and Other Polar Compounds. J Chromatogr. 1990. 499. 177-196.

Alexander, L, N. Application of Hydrophilic Interaction Liquid Chromatography for the Analysis of Polar Contaminants in Food and Environmental Science. $J$. Chromatogr. 201

Alpert, Andrew J. Hydrophilic-interaction chromatography for the separation of peptides, nucleic acids and other polar compounds. J. Chromatogr. 1990. 499: 177-196.

Alpert, Andrew J. Electrostatic Repulsion Hydrophilic Interaction Chromatography for Isocratic Separation of Charged Solutes and Selective Isolation of Phosphopeptides. Anal. Chem. 2008. 80: 62-76.

Alpert, Andrew J. Peptide Orientation Affects Selectivity in Ion-Exchange Chromatography. Anal. Chem. 2010. 82: 5253- 5259

Braithwaite, A, Smith, F, J. Chromatographic Methods. Netherlands. 1999

Carrier, R, Bordanaro, J, Yip, K. Liquid Chromatography. 1997
Ding, W. Identification and Quantification of Glycoproteins Using Ion-Pairing Normal-Phase LC and MS. Molecular \& Cellular Proteomics 2009. 8: 21702185.

Eric S. Grumbach. Hydrophilic Interaction Chromatography Using Silica Columns for the Retention of Polar Analytes and Enhanced ESI-MS Sensitivity. 1999. LCGC Magazine.

Grimmet, M. Ross. Imidazole and Benzimidazole Synthesis. Academis Press

Guo Yong, Gaiki Shetal. Retention Behavior of Small Polar Compounds on Polar Stationary Phases in Hydrophilic Interaction Liquid Chromatography. $J$. Chromatogr. 2005. $71-80$

Ikegami T. Separation Efficiencies in Hydrophilic Interaction Chromatography. J. Chromatogr. 2008. 1184. $474-503$

Jandera, Pavel. Stationary Phases and Mobile Phases in Hydrophilic Liquid Chromatography. Analytica Chemica Acta 2011. 692. 11 -25

Michael, Cooke. Encyclopedia of Separation Science. USA

McKay, P. 2010. An Introduction to Chromatography.

Qiu, Hongdeng. Preparation and Evaluation of a Silica-based 1-alkyl-3(propyl-3sulfonate) Imidazolium Zwitterionic Stationary Phases for High Performance Liquid Chromatography. J. Chromatogr. 2007. 1163. $63-69$

Rees. 1984. Comprehensive Heterocyclic Chemistry. Vol 5. Page 469-498

Takeuchi T, Kawasaki T, Lim L. Separation of Inorganic Anions on a Pyridine Stationary Phase in Ion Chromatography. Analytical Science. 2010. Vol 26. 511 - 514Watson, G.D. The Hydrophilic Interaction Like Properties of Some Reversed Phase High Performance Liquid Chromatography Columns in The Analysis of Basic Compounds. $J$. Chromatogr. 2011. 1128. 1486 - 1491 
Dyna Putri Mayaserli, Pemisahan Anion Menggunakan Fasa Diam Hilic Imidazol

Willey, John \&Sons. 2004. Practical High Performace Liquid Chromatography. Fourth Edition. Switzerland

Yoshida, T. Peptide Separation in Normal Phase Liquid Chromatography. Analytical Chemistry. 1997. 69. 30383043.
Zein, R. Munaf, E. Takeuchi, T. Miwa, T. Application of microcolumnion chromatography using octadecylsilica immobilized with bovine serum albumin as stationary phase for the determination of inorganic anions. Journal of Abalitical Chemistry. 1996. 357 (4): 466 -468 . 